\title{
Psychological Flexibility, Coronavirus Anxiety, Humor and Social Media Addiction During COVID-19 Pandemic in Turkey
}

\section{Şeyma Güldal ${ }^{1} \oplus$ - Nur Akbulut Kılıçoğlu ${ }^{1} \cdot$ Figen Kasapoğlu ${ }^{1}$}

Accepted: 15 December 2021/ Published online: 28 January 2022

(c) The Author(s), under exclusive licence to Springer Science+Business Media, LLC, part of Springer Nature 2021

\section{ABSTRACT}

Psychological flexibility is associated with psychological health and affected by various factors. The aim of the present study is to examine the role of coronavirus anxiety, humor and social media addiction on psychological flexibility during the COVID-19 pandemic in Turkey. Variables were measured with online self-report surveys and data were gathered from December 2020 to January 2021 in Turkey. The sample consisted of 376 people (295 female, $\mathrm{M}=29.88, \mathrm{SD}=11.05$ ). The relationships between the variables were tested with path analysis using structural equation modelling (SEM). According to results, the constructed model showed that COVID-19 anxiety significantly and directly increased social media addiction $(\beta=.17, \mathrm{p}<.01)$, decreased coping humor $(\beta=-.11, \mathrm{p}<.05)$ and decreased psychological flexibility indirectly through social media addictions $(\beta=-.08, p<.01)$. Humor coping significantly and directly increased psychological flexibility $(\beta=.25$, $\mathrm{p}<.01$ ), and social media addiction significantly and directly decreased psychological flexibility $(\beta=-.31, p<.01)$. Findings indicated that psychological flexibility is influenced by coronavirus anxiety, social media addiction and humor coping. Supporting humor coping and reducing anxiety and problematic social media use would be helpful to enhance psychological flexibility of individuals during the pandemic.

Keywords Psychological flexibility · Coronavirus disease (COVID-19) · Anxiety · Humor $\cdot$ Social media addiction

Şeyma Güldal

seymatozlu@gmail.com

Nur Akbulut Kılıı̧oğlu

nakilicoglu@29mayis.edu.tr

1 Department of Psychological Counseling and Guidance, Istanbul 29 Mayıs University, Elmalıkent Mah. Elmalıkent Cad. No:4 34764, Ümraniye, Istanbul, Turkey 


\section{Introduction}

COVID-19 pandemic spread all over the world in a sort time and negatively affected both individuals and countries socially, economically, and psychologically. Governments carried out some restrictions and precautions like quarantines, lockdowns, working from home, distance education that resulted in changes the daily lives of many people (Bonaccorsi et al., 2020; Han et al., 2020; Landi et al., 2020). The most common psychological consequences of pandemic related stressors includes generalised mood disorders, anxiety disorders, post-traumatic stress disorders, and depression (Taylor, 2019). According to the results of studies, (Bendau et al., 2021; Liu et al., 2020; McCracken et al., 2021; Wang et al., 2020;) almost more than half of the individuals reported severe to moderate anxiety and depressive symptoms. Adaptive coping including the use of humor (Amici, 2020) or maladaptive coping strategies like excessive use of social media (Cauberghe et al. 2020) have an impact on the level of pandemic anxiety and related negative emotions (Rasskazova et al, 2020). Anxiety level of individuals during COVID-19 outbreak is also associated with other factors like psychological flexibility which is a resilient factor for mental health (McCracken et al., 2021). Psychological flexibility as an essential part of psychological health has a great role in supporting people at high risk of poorer mental health effects because of anxiety during a pandemic (Dawson \& Golijani-Moghaddam, 2020; Landi et al., 2020; McCracken et al, 2021). Thus, it is important to understand the factors related to psychological flexibility to improve individuals' mental health during the pandemic time.

\section{Psychological Flexibility}

Relational frame theory (RFT) asserts that language and cognition play a great role on psychological problems (Hayes et al., 2001). In this approach, the context and the function of psychological events are given attention rather than the content, form, and frequency with which they occur (Hayes et al., 2011). Acceptance and commitment therapy (ACT) which benefits from relational frame theory is an evidence-based therapeutic approach combining acceptance and mindfulness approach with commitment and behavior change methods in order to improve psychological flexibility (Hayes et al., 2009).

Psychological flexibility model in acceptance and commitment therapy explains psychological health and functional behaviors through six core dimensions including contact with the present moment, committed action, acceptance, cognitive defusion, values, and self-as context. Contact with the present moment means paying attention to what is happening right now. Committed action is doing what is important for one's life, living by own values. Acceptance refers embracing of moment-to-moment experience actively and voluntarily. Cognitive defusion is the ability to distinguish thoughts and direct experiences, that is, thoughts are just thoughts not facts. Values mean what is important for a person 
and guiding principles that direct one's life. Finally, self-as-context includes the experience that a person is not the content of her/his thoughts, but the one experiencing it (Chin \& Hayes, 2017; Hayes et al., 1999; Hoffmann et al. 2019). Its negative form is called as psychological inflexibility which explains being in a psychologically unhealthy state (Fig. 1).

In ACT, the dimensions of psychological flexibility are mechanisms of change (Ciarrochi et al., 2010). There are evidences supporting the efficacy of acceptance and commitment therapy (ACT) for chronic pain (Scott \& McCracken, 2015), substance use (Smout et al., 2010), somatization, depression, anxiety (Masuda and Tully 2012; White et al., 2013) and posttraumatic stress (Twohig, 2009). Recently, results of the studies related to the COVID-19 pandemic supported that psychological flexibility is a resilience factor reducing the adverse effects of the COVID-19 including depression, anxiety, insomnia (McCracken et al., 2021; Pakenham et al. 2020; Wielgus et al., 2020), stress (Arslan \& Allen, 2021), and supporting adaptive COVID-19 coping responses (Dawson \& Golijani-Moghaddam, 2020), well-being (Arslan \& Allen, 2021).

\section{Coronavirus Anxiety}

The COVID-19 pandemic results in both physical health and psychological resilience challenges. The disease rapidly spread around the world and became an international outbreak. Increasing rate of infected cases and associated deaths brought an enormous panic and anxiety in public (Lin, 2020). Psychological impacts of COVID-19 outbreak, especially depression, anxiety and stress-related symptoms, have been examined with variety of populations including healthcare workers (Yeni-Elbay et al., 2020; Pouralizadeh et al. 2020), patients (Hajure et al., 2020), teachers (Li et al., 2020), adolescents (Liu et al. 2020) and general population (Özdin and Bayrak-Özdin 2020; Wang et al., 2020) all around world. Especially, anxiety results from COVID-19 disease is common

Fig. 1 Dimensions of Psychological Flexibility Model. Note. This figure demonstrates the six core dimensions of psychological flexibility model in Acceptance and Commitment Therapy. From "Acceptance and commitment therapy: Model, processes and outcomes" by S. C. Hayes, J. B. Luoma, F. W. Bond, A. Masuda, A., \& J. Lillis, 2006, Behaviour Research and Therapy, 44(1), 8. Copyright 2005 by Elsevier Ltd

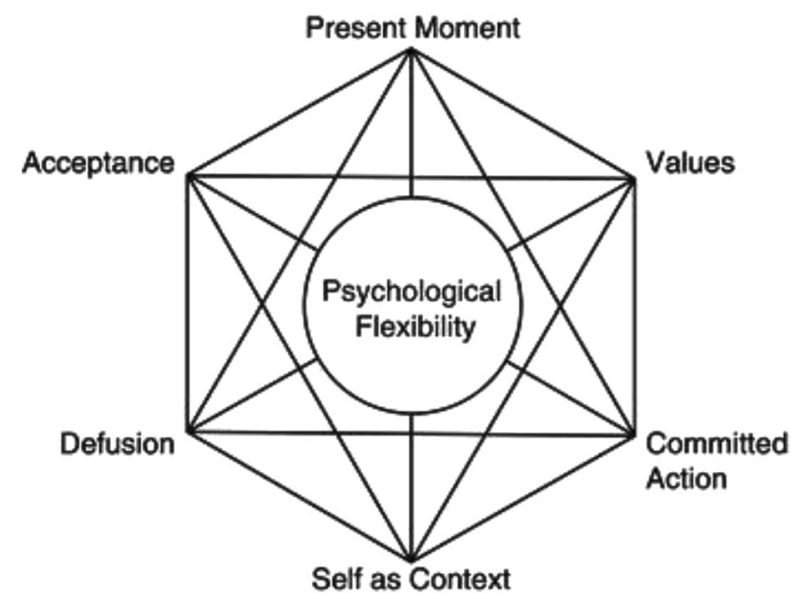


among people from different ages, professions and countries (Da Silva et al., 2021; Yeni-Elbay et al. 2020).

The term coronavirus anxiety is based on the psychology of fear and anxiety literature. Trauma related reactions, anxiety as well as distressing bodily symptoms are at the center of coronavirus anxiety (Lee, 2020). COVID-19 pandemic resulted in anxiety among people due to the lockdowns determined by governments and social isolation. Furthermore, the reasons for fear are the severity of the disease, risk of crisis, the economic and financial impact on families as well as fear about life (Da Silva et al., 2021). Genetics, personality, past traumas and substance abuse recognizing in several ways like muscle pain, excessive worry, indigestion and sleep disorders are the factors that can increase anxiety rates (McAlonan et al., 2007).

\section{Coping With Humor}

Individuals can use various ways to cope with stressful and troublesome situations in life. Coping with humor, one of these ways, has become a frequently researched topic in recent years (Brunault et al, 2015; Satıcı \& Deniz, 2017; Vela et al., 2013). It has been stated that humor is very important in protecting one's self in daily life, maintaining a positive mood and coping with traumatic experiences (Barry, 1994; Frankl, 1966; Ruch, 1998). Studies conducted in this context support that humor is a way to cope with stress and troubles (Abel, 2020; Fritz et al. 2017; Nezlek \& Derks, 2001) because humor has been found to facilitate coping with stressful situations by contributing to cognitive reassessment (Kuiper et al., 1995). Based on the knowledge that humor is effective in coping with stress, according to Kuiper et al. (1993), using humor as a coping mechanism in a stressful situation is an important self-protection strategy. In addition, humor was found to be related to subjective well-being (Özbay et al., 2012) and psychological well-being (Maiolino \& Kuiper, 2016). In fact, it is seen that individuals who use humor as a coping method are healthier and less depressed, and they are also liked by their social environment and are strong against psychological disorders (Celso et al., 2003; Nezlek \& Derks, 2001). In other words, humor is a protective factor against psychological disorders (Thorson et al., 1997; Brunault et al., 2015) and is thought to have a positive relationship with the concept of psychological flexibility defined as the capacity of a person to cope with traumatic events, to have balanced, productive and positive emotions, and to have a healthy level of psychological and physical functionality (Bonnano, 2004). Humor as a coping mechanism has a predictive value for psychological flexibility which is one of the fundamental aspects of psychological health (Pilz, 2018; Rieger \& McGrail, 2013). Therefore, it is thought that humor will positively affect the psychological flexibility of individuals and it is an effective defense method that can be used to cope with the fear of coronavirus, which is frequently observed during the pandemic period. 


\section{Social Media Addiction}

Social media addiction was another concept which was examined in this study. According to January 2021 digital report of We Are Social platform which provides the latest Internet statistics for Turkey and includes mobile and social statistics, social media users increased by 6 million that is more than $11 \%$ compared to the previous year. The number of social media users in Turkey with this data equal to $70.8 \%$ of our total population. Considering the purposes of using social media, the first place is to follow the agenda, to be informed about news and events, to watch entertaining videos and content, to fill leisure time, to interact with friends and family members, to share photos and videos. From this point of view, most of the users spend their time on social networks, online news sites, movie and music pages. Internet and social media usage increased with the impact of COVID-19. Since last year, the number of social media users has increased by $13 \%$ (WeAreSocial, 2021). Social media addiction is basically considered as a behavioral addiction (Griffiths, 2005, p.191). Studies have reported that approximately $12 \%$ of social media users experience social media addiction (Alabi, 2012; Wolniczak et al., 2013; Wu et al., 2013).

Researchers suggested that the overuse of new technologies (especially online social networks) can create a potential mental health problem, loneliness and addiction in young people (Al-Kandari \& Al-Sejari, 2021; Echeburua \& de Corral, 2010; Stankovska et al., 2016). Addiction causes individuals to socialize less and their social relationships to deteriorate (Savc1 \& Aysan, 2017; Balc1 \& Tiryaki, 2014). According to the research, uncontrolled use of social media decreases self-esteem (De Cock et al., 2014; Pelling \& White, 2009), increases loneliness (Özgür, 2013; Sagioglou and Greitemeyer 2014) decreases life satisfaction (Chan, 2014; Valenzuela et al., 2009) and causes depression (Blachino et al., 2015; Khattak et al., 2017; Steers et al., 2014). In addition, some studies have shown that individuals who spend time on social media for a long time exhibit poor academic performance (Junco, 2012; Karpinski et al., 2013; Kirschner \& Karpinski, 2010).

With the COVID-19 pandemic, people's lives have started to change both individually and socially (Taylor et al., 2020). It has been found that staying at home for a long time, social distance and hygiene measures gradually increase anxiety and negative mood in individuals (Gao et al., 2020). There are various studies on internet addiction during the COVID-19 pandemic. Based on the knowledge that the vast majority of internet users are social media users, it is thought that internet addiction and COVID-19 research will yield similar results on social media addiction. According to these studies, it has been found that with the COVID-19 pandemic, individuals increase internet use to cope with the resulting stress and anxiety and this increase may have an impact on the development of internet addiction disorder in some individuals (Gao et al., 2020; Király et al., 2020). In addition, a recent study found that problematic Internet use does not significantly affect fear of COVID-19, but anxiety mediates this effect (Hashemi et al., 2020). When the research is examined, it is seen that more research is required in order to better understand the relationship between social media addiction and the fear of COVID-19. 


\section{Present Study}

Throughout the life, every individual encounters some difficulties. During these times, the ability to adjust to the situations by accepting that life can have positive aspects as well as negative aspects gains importance. Instead of avoiding the unwanted experiences, psychological flexibility serves as a core mechanism in order to cope with life struggles and support mental health (Hayes et al., 2006). Thus, it is important to explore the factors related to psychological flexibility to enhance mental health of people during pandemic.

With social life restrictions altering daily life, death rates, health problems, isolations, and ambiguity, COVID-19 outbreak negatively affect most of the indivuduals' mental health by increasing anxiety levels (Liu et al., 2020; McCracken et al., 2021; Wang et al., 2020). It is known that anxiety lowers psychological flexibility because it generally results in experiential avoidance and cognitive fusion (White et al., 2013). Furthermore, excessive social media use represents avoidance behavior that is trying or controlling unpleasant experiences and leads to reduce in psyhological flexibility (Chou et al., 2017). Also, systematic reviews indicate that there is an association between problematic social media use and mental health problems including anxiety issues (Keles et al., 2019; Marino et al., 2018). On the other hand, there is less study about humor and psyhcological flexibility but Pilz's study (Pilz 2018) showed that adaptive humor styles positively correlated with psychological flexibility. It also protective factor against anxiety (Menéndez-Aller et al., 2020; Smith et al., 1971). Considering all of the empirical evidences, it may assume that anxiety, social media addiction, and humor has a direct relationship with psychological flexibility. Moreover, anxiety has a relationship with social media addiction and humor, and these two mediate the relationship between anxiety and psychological flexibility.

In this study, we aimed to investigate the factors related to psychological flexibility during the COVID-19 pandemic. Besides, there is not any study investigating the relationship between humor as coping mechanism, social media addiction and psychological flexibility among adults. The main aim of the study is to explore the relationship between coronavirus anxiety, problematic social media use, coping humor, and psychological flexibility. We hypothesized that psychological flexibility is directly and positively associated with coping humor, and negatively related to social media addiction and coronavirus anxiety. It is also indirectly associated with

Fig. 2 Tested Model

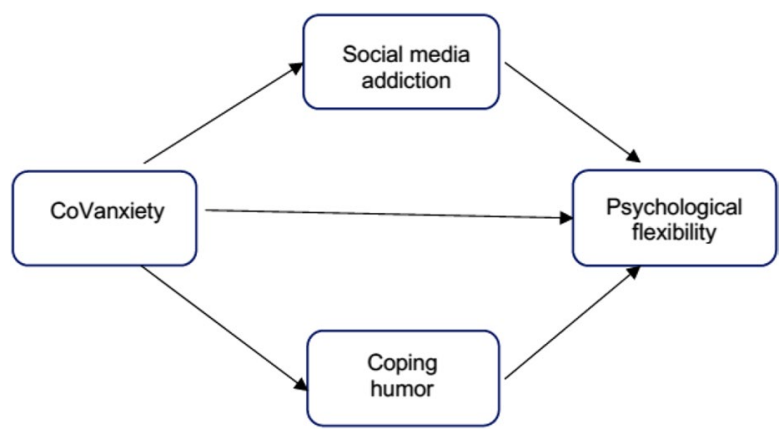


anxiety through social media addiction and coping humor. Based on the results, a path model will be constructed to show the interrelationship between coronavirus anxiety, problematic social media use, coping humor and psychological flexibility. The diagram of the Model created to test these relationships is presented below (Fig. 2).

\section{Methods}

\section{Participants and procedure}

Convenience sampling method was used (Gravetter \& Forzano, 2012) to gather data from adult participants who are over 18 years. Individuals approved online consent form and completed survey in Turkish. The data were collected via online survey software which is Google Forms, taking into account social isolation due to the COVID-19 outbreak. Completing the survey took approximately 10 to $15 \mathrm{~min}$. Data were collected from people living in Turkey during December to January, 2020. The study was approved by the Ethics Committee of Istanbul 29 Mayis University (Approval code: 2021/01-03) and conducted in accordance with the Declaration of Helsinki.

The sample of the study contained 376 participants and most of them were female [295 female 78.5\%) and 81 male (\%21.5)]. Kline (2015) suggested that an average sample size for structural equation model could be approximately 200 cases based on reviews of studies in different research areas, including education and psychology. Therefore the sample size of 376 was considered sufficient for this study. The average age of the participants was 29 years and range from 18 to 67 years $(M=29.88, S D=11.05) .178$ of the participants were working $(47.3 \%), 38$ of them were not working $(10.1 \%)$ and 160 of them were students $(42.6 \%)$.

\section{Measures}

\section{Coronavirus Anxiety Scale}

The scale was developed by Lee (2020) to identify cases of dysfunctional anxiety associated with the COVID-19 crisis. The scale is a one-dimensional 5-point Likert-type $(0=$ never, $4=$ every day for the last two weeks) scale with 5 items. The scale was translated into Turkish by Akkuzu and colleagues (Akkuzu et al., 2020). In exploratory factor analysis, a single factor structure of the scale explained $58 \%$ of the total variance. Fit indices were within acceptable limits in the confirmatory factor analysis $\left(\chi^{2}=52,204 ; \mathrm{p}<0,001 ; \chi^{2} / \mathrm{sd}=10 ; \mathrm{GFI}=0,98\right.$; AGFI $=0,95$; $\mathrm{CFI}=0,97$; RMSEA $=0,09)$. The internal consistency reliability coefficient was calculated to be 0.82 and test-retest reliability as $r=0.88$. High scores on the scale reflect high coronavirus anxiety. 


\section{Psychological Flexibility Scale}

The scale was developed by Francis et al. (2016) and adapted into Turkish by Karakuş and Akbay (2020). Factor analysis revealed factor loadings between 0.47 and 0.81 . The scale explained $60 \%$ of the variance. The 7-point Likert-type scale consisted of 28 items and 5 factors. Values and behavior in values, being in the moment, acceptance, self as context, and decomposition comprised the 5 sub-dimensions. The internal consistency reliability coefficient of the scale was calculated to be 0.79 . The reliability scores for the sub-dimensions were 0.84 for values and behavior in values, 0.60 for being in the moment, 0.72 for acceptance, 0.73 for self as context, and 0.59 for decomposition. High scores on the scale reflect high psychological flexibility.

\section{The Coping Humor Scale (CHS)}

The scale was developed by Martin and Lefcourt (1983) and adapted into Turkish by Yerlikaya (2009). The scale is used for determining the individual levels of coping with humor. The CHS is a one-dimensional 4-point Likert-type with 7 items. The possible scores range between 7 and 28, where a higher score represents better ability of the individual to use humor as a coping strategy in stressful situations. The adaptational study of the scale tested its criterion-related validity and reported an internal consistency reliability coefficient of 0.67 and that CHS significantly and negatively correlated with perceived stress, depression, and state and trait anxiety.

\section{Bergen Social Media Addiction Scale}

The scale was developed by Andreassen and colleagues (2016) and adapted into Turkish by Demirci (2019). In exploratory factor analysis, the scale explained $52.83 \%$ of the variance. The scale is a one-dimensional 5-point Likert-type scale with 6 items. The one-dimensional model had acceptable fit indices in the confirmatory factor analysis $(\chi 2=10.80, \mathrm{df}=9, \mathrm{p}=0.29 ; \mathrm{CFI}=0.99$; $\mathrm{TLI}=0.99$; SRMR $=0.031$; RMSEA $=0.039)$. The scale was found to have an internal consistency reliability coefficient of 0.82 and a test-retest reliability coefficient of 0.83 . High scores on the scale reflect high social media addiction.

\section{Statistical Analyses}

The present study investigated the relationships between COVID-19 anxiety, humor coping, social media addiction and psychological flexibility. First, descriptive statistics (mean, standard deviation, skewness, and kurtosis) were calculated. The relationships between the variables were tested with path analysis using structural equation modelling (SEM). In the first step, the suitability of the data for structural equation modeling (SEM) analysis was examined. For SEM analysis, multicollinearity and normality were explored (Teo et al., 2013) and the VIF values were found below 10 that indicates no multicollinearity in the data 
set (Kline, 2015). For the assumption of normality, skewness and kurtosis values were calculated. It was found that the skewness of the variables varied between -0.13 and 1.82 while the kurtosis values varied between -0.74 and 2 . For a normal distribution, skewness and kurtosis values within the range of -2 and +2 are considered as acceptable (George \& Mallery 2009). Therefore, the results showed that the data were suitable for SEM analysis. In order to evaluate the adequacy of the structural model (Kline, 2015), $\chi^{2}$ /df ratio, SRMR, RMSEA, CFI, and NFI were calculated. $95 \%$ confidence interval was used for ensuring the significance of the indirect and direct effect of the variables that were included in SEM, in addition to application of Bootstrap analysis through 10,000 re-sampling (Preacher \& Hayes, 2008). Data analyses were conducted using IBM SPPS Statistics and AMOS Graphics package.

A mediation model was used to examine direct and indirect effects of COVID19 anxiety through social media addiction and humor coping. SEM analysis was performed in order to test the mediation model. The mediation model investigated the mediator variable's effect, which explains the relationship between independent and dependent variables, as well as the effects of the independent variables on the dependent variable (Baron \& Kenny, 1986). Baron and Kenny (1986) stated there were steps to testing mediation: (1) significant relationship between the independent variable and the mediation variable is needed, (2) significant relationship between the mediation variable and dependent variable is needed, (3) relationship of independent variable to dependent variable diminishes when mediation model is added to the model. On the other hand, the initial steps outlined by Baron and Kenny have changed. The first step that direct effect of independent variable on dependent variable needs to be significant is not a requirement anymore. Indirect effects can exist even if a non-significant direct effect is initially found. The justification is based on the idea that there are suppressor effects that prevent the direct effect from being significant, but the indirect effect is still present (Collier, 2020, p. 172).

Table 1 Correlation Matrix and Descriptive Statistics

\begin{tabular}{lllll}
\hline & $\begin{array}{l}\text { COVID-19 } \\
\text { anxiety }\end{array}$ & Humor coping & $\begin{array}{l}\text { Psychological } \\
\text { flexibility }\end{array}$ & $\begin{array}{l}\text { Social } \\
\text { media } \\
\text { addiction }\end{array}$ \\
\hline COVID-19 anxiety & - & $-0.108^{*}$ & $-0.147^{* *}$ & $0.170^{* *}$ \\
Humor coping & & & $0.248^{* *}$ & 0.009 \\
Psychological flexibility & & & $-0.312^{* *}$ \\
M & 0.90 & 18.61 & 132.02 & 16.6 \\
SD & 1.56 & 3.81 & 16.24 & 5.88 \\
Skewness & 1.83 & -0.01 & -0.13 & 0.13 \\
Kurtosis & 2.1 & -0.05 & 0.69 & -0.74 \\
Cronbach Alpha & 0.68 & 0.69 & 0.77 & 0.83 \\
\hline
\end{tabular}

$N=376 ; * * p=0.01 ; * p=0.05$ 


\section{Results}

The descriptive statistics and correlation coefficients of the study variables are displayed in Table 1. The skewness values of the variables range from -0.13 to 1.82 and kurtosis values are between -0.74 to 2 . As such, the data represent normal distribution (-2.00 to 2.00) (George \& Mallery, 2009). The internal consistency coefficients of the scales were found to be on acceptable levels ( $\alpha=0.67$ to 0.83 ) (Büyüköztürk et al, 2010). According to Tavşancil (2010) and Özdamar (2002), if the Cronbach $\alpha$ coefficient of the scale is less than 0.40 , the measurement tool is not reliable, between $0.40-0.59$ has low reliability, and between $0.60-0.79$ it is reliable. When it is between 0.80 and 1.00 , it is considered as highly reliable. The correlational analysis revealed a statistically significant negative correlation of COVID-19 anxiety with humor coping and with psychological flexibility $(\mathrm{r}=-0.11, \mathrm{p}<0.05$; $\mathrm{r}=-0.15, \mathrm{p}<0.01$, respectively) and a statistically significant positive correlation of COVID-19 anxiety with social media addiction $(\mathrm{r}=0.17, \mathrm{p}<0.01)$. Additionally, a statistically significant positive correlation between humor coping and psychological flexibility $(\mathrm{r}=0.25, \mathrm{p}<0.01)$ and a negative correlation between psychological flexibility and social media addiction $(r=-0.31, p<0.01)$ were found. There was no statistically significant relationship between humor coping and social media addiction $(\mathrm{r}=0.01, \mathrm{p}>0.05)$.

\section{Path Analysis}

Table 1 shows that there is a significant relationship between the independent variable COVID-19 anxiety and the mediator variables social media addiction and humor coping. Another significant relationship was found between the mediator variables social media addiction, and humor coping and the dependent variable psychological flexibility. There is no significant relationship between social media addiction and humor coping, which is the other mediator variable. A significant relationship was found between COVID-19 anxiety and the dependent variable psychological flexibility. Since 5 out of 6 relationships were found to be significant; it was concluded that a mediation model could be created between these variables. Therefore, indirect and direct paths to psychological flexibility were tested from COVID-19 anxiety variable to psychological flexibility through social media addiction and humor coping. In the first model, the partial mediating role of social media addiction and humor coping in the relationship between COVID-19 anxiety and psychological flexibility were tested. Direct and indirect path coefficients from COVID-19 anxiety through social media addiction and humor coping to psychological flexibility were examined. The tested model adequately fitted with the data $\left[\left(\chi^{2 / \mathrm{df}}(1)=2.87\right.\right.$, $\mathrm{p}=0.59)$, RMSEA $=0.000, \mathrm{CFI}=1.00, \mathrm{TLI}=0.97, \mathrm{GFI}=1.00$, AGFI $=0.99]$. However, there were no statistically significant direct path coefficient between COVID19 anxiety and psychological flexibility $(\beta=-0.07, p=0.15)$. Secondly, only indirect path coefficients from COVID-19 anxiety through social media addiction and humor coping to psychological flexibility, the modified model was tested. The tested 
Fig. 3 The path coefficients between the path analysis and the variables. $* \mathrm{p}=.03, * *$ $\mathrm{p}=.001, * * * \mathrm{p}<.001$

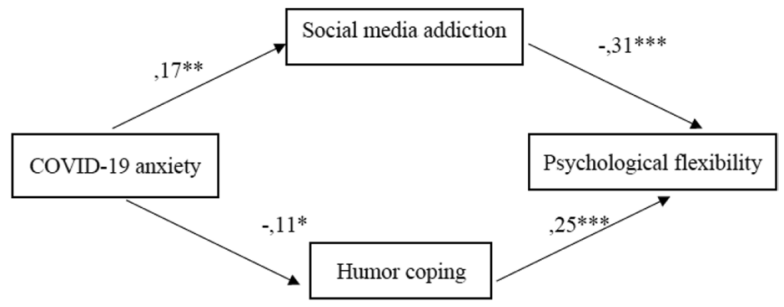

model adequately fitted with the data $[(\chi 2 / \mathrm{df}(2)=1.18, \mathrm{p}=0.31), \mathrm{RMSEA}=0.022$, $\mathrm{CFI}=0.995, \mathrm{TLI}=0.986, \quad \mathrm{GFI}=0.997, \quad \mathrm{AGFI}=0.984, \quad \mathrm{SRMR}=0.018](\mathrm{Hu} \&$ Bentler, 1999; Kline, 2015; Şimşek, 2007). Therefore, the second model (the full mediating model) was preferred because of the insignificant path in the partial mediating model. These results generally showed that COVID-19 anxiety predicted indirectly psychological flexibility through social media addiction. The standardized path coefficients for the second Model were presented in Fig. 3.

To support the significance of the indirect effects of the COVID-19 anxiety to psychological flexibility, a 95\% confidence interval was selected and the bootstrap analysis was applied through 10,000 re-sampling. According to SEM results, COVID-19 anxiety, social media addiction $(\beta=0.17, p=0.001,95 \% \mathrm{CI}=0.073$, $0.264)$, and coping with humor $(\beta=-0.11, \mathrm{p}=0.03,95 \% \mathrm{CI}=-0.198,-0.010)$ estimates significantly. Also social media addiction $(\beta=-0.31, \mathrm{p}<0.001, \% 95$ $\mathrm{CI}=-0.394,-0.231)$, and humor coping $(\beta=0.25, \mathrm{p}<0.001, \% 95 \mathrm{CI}=0.164,0.335)$ significantly predicted psychological flexibility. The results of the study generally imlpy that the indirect effect of COVID- 19 anxiety on psychological flexibility through social media addiction $(\beta=-0.55, \mathrm{p}=0.002,95 \% \mathrm{CI}=-0.995,-0.206)$, and humor coping $(\beta=-0.28, p=0.013,95 \% \mathrm{CI}=-0.595,-0.052)$ were statistically significant. The standardized path coefficients for the model are presented in Table 2.

\section{Discussion}

The present study examined the relationship of psychological flexibility with COVID-19 anxiety, humor coping, and social media addiction. Path analysis was conducted to determine the effect of COVID-19 anxiety, humor coping, and social media addiction on psychological flexibility. COVID-19 anxiety directly and significantly increased social media addiction while decreasing humor coping levels. Social media addiction directly and significantly decreased psychological flexibility. Humor coping directly and significantly increased psychological flexibility. Additionally, COVID-19 anxiety indirectly and significantly decreased psychological flexibility.

Results showed that coronavirus anxiety has a positive relationship with social media addiction. During the COVID-19 pandemic, the role of the social media has become widely crucial as a source of information and communication. However, frequency, duration, and diversity of media exposure are positively related to more 


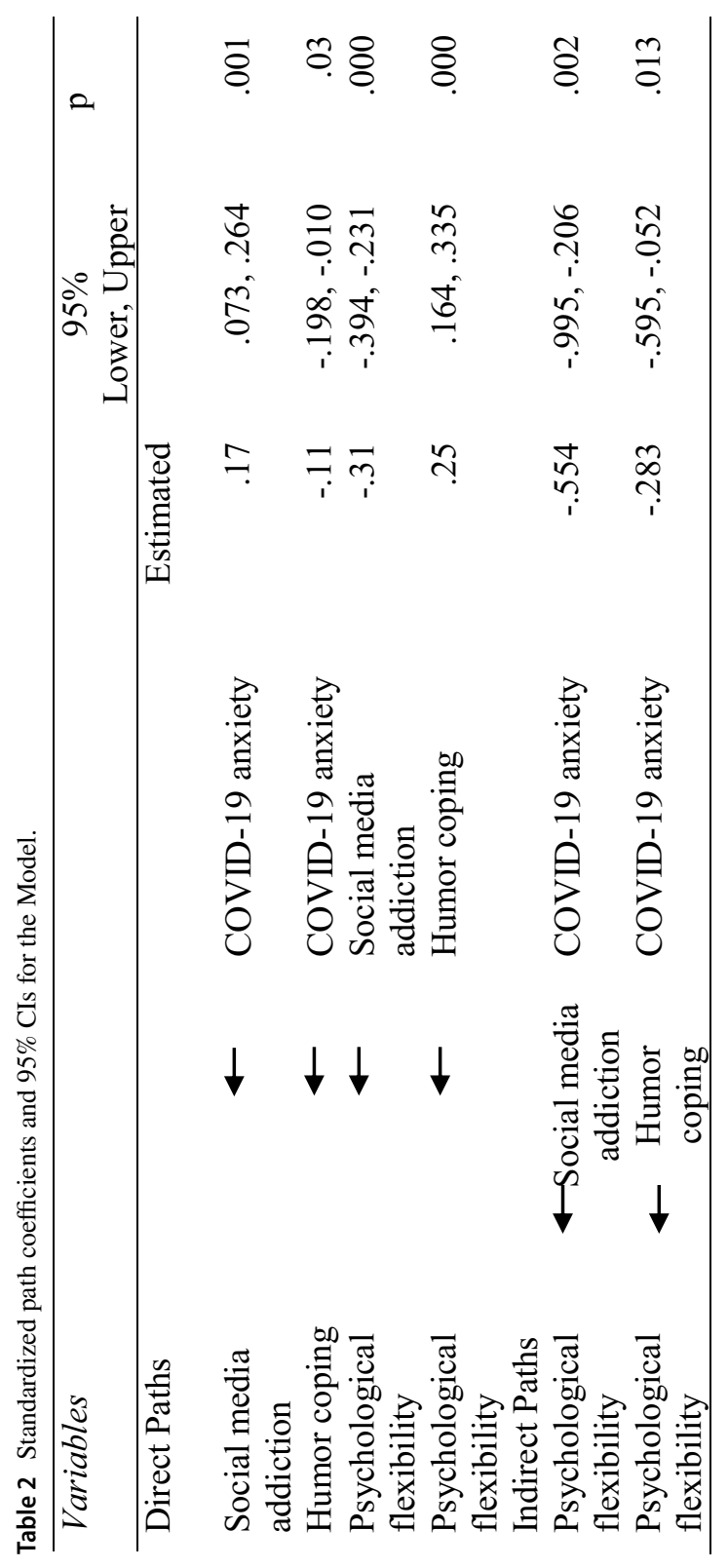


symptoms of COVID-19 specific anxiety (Bendau et al., 2020). People with higher anxiety about coronavirus tend to use social media more frequently and for a long period of time. This addictive use of social media may be a coping mechanism for coronavirus anxiety as well as side effects of the pandemic including social isolation and loneliness. Anxious people using more social media may try to adapt current situation. Similarly, the results of Cauberghe and her collagues's (2020) study indicated that adolescents frequently use social media to cope with feelings of loneliness and anxiety during COVID-19 lockdown.

The findings indicated that the level of coronavirus anxiety does not directly affect psychological flexibility but indirectly decreases psychological flexibility through social media addiction. As discussed in the previous paragraph, people's social media addiction increases as their COVID-19 anxiety rises, and the resulting addiction reduces their psychological flexibility. There is a mediator variable in the indirect effect of anxiety on psychological flexibility. Experiential avoidance is one of the six aspects of psychological inflexibility that is mentioned in the ACT Psychopathology Model, which is manifested by reduced psychological flexibility (Hayes et al., 2006), and is particularly evident in different forms of addiction. Addictions including social media addiction frequently serve the purpose of controlling or diminishing undesirable thoughts, feelings or any other experiences (Wilson et al., 2000). Excessive use of social media may offer anxious people to avoid uncomfortable experiences that may influence psychological flexibility during COVID-19 pandemic. In other words, while the person avoids anxiety, the behavioral repertoire begins to narrow (Twohig, 2012). It is defined as the narrowing of the behavioral repertoire of the individual, who has to spend a long time in a certain area with the call to stay at home and the curfews applied at certain times, turning to social media whenever he has a negative thought about today and the future. This will lead to the deterioration of the person's psychological, familial, social and professional functionality. According to the result of our research, this explains the role of social media addiction as a mediating variable, negatively affecting psychological flexibility, as the anxiety of COVID-19 increases.

This study showed that social media addiction significantly decreases psychological flexibility. The relationship between social media addiction and psychological flexibility has not been specifically studied before. However, psychological flexibility is a feature strengthening the mood and makes it easier to cope with difficult and stressful events. Studies examining the relationship between social media addiction and depression, life satisfaction, psychological resilience, etc. provide predictive perspectives about the relationship between social media addiction and psychological flexibility. Studies have revealed that there is a positive and significant relationship between intensive internet/ social media use and depression (Agrawal \& Singh, 2018; Eraslan-Capan, 2015; Hoare et al., 2017; Scherr \& Brunet, 2017). According to the study of Donnelly and Kuss (2016), people with social media addiction and long hours of Instagram use also had significant depression. Similarly, Hoare et al. (2017) stated that individuals with problematic internet use have high levels of depressive symptoms. According to the findings of the study of Soysal (2016), which deals with the relationship between Facebook addiction and psychological resilience, there is a negative and significant relationship between Facebook 
addiction and psychological resilience. In short, as people's addiction to Facebook increases, their psychological resilience levels decrease. Similiar to our results, all these studies support the finding that social media addiction reduces psychological flexibility.

According to the results, there is a negative and significant correlation between coronavirus anxiety and humor as a coping style. Studies showed that positive use of humor has anxiety-lowering effect and serves as a protective factor against the symptoms of anxiety (Ford et al., 2012; Menéndez-Aller et al., 2020; Szabo, 2003). Conversely, as anxiety level increases, the use of humor as a form of coping decreases. However, humor has a positive relationship with psychological flexibility and moderates the negative effect of coronavirus anxiety on psychological flexibility. Similar to our finding, Pilz (2018) found that adaptive humor styles have a positive relationship with psychological flexibility. Pilz (2018) concluded in a study conducted with 245 participants that there is a potentially significant relationship between psychological flexibility and adaptive humor styles. It is stated that selfenhancing humor style which is benevolent is used to improve the self and is an effective method used to cope with stressful and challenging situations. The affiliative humor style is also benevolent but is used to develop social relationships with other people (Martin et al., 2003). The findings of Pilz (2018) are thought to support the findings of this study.

On the other hand, counselors and other mental health professionals may benefit from acceptance commitment therapy (ACT) to help their clients to manage their anxiety and problematic social media use. They should consider the results of this study that the relationship between psychological flexibility, coronavirus anxiety, and social media addiction. It could be argued that problematic social media use serves as an avoidance behavior which undermines psychological flexibility. According to relational frame theory, because of the relational repertoire of language-able individuals, once a specific event acquires avoidance functions a large number of applicable contextual cues can elicit the same response (Vilardaga et al., 2012). Surely, evaluating and intervening this "unwanted" behavior by exploring the function of the behavior would be appropriate. Different types of behaviors may begin as pleasurable, but the outcome is actually a result of escape (Rachlin, 2000). In this situation, ACT interventions help individuals to reduce experiential avoidance underlying the compulsive behavior of social media use. It supports them to accept unpleasant experiences, create meaningful lives based on values, and commit to useful actions inspite of negative experiences (Hayes \& Levin, 2012; Hayes \& Smith, 2006). As applied to anxiety problems, ACT aims to encourage more flexible and mindful ways of relating to anxiety, and thus people can pursue their valuable life goals (Eifert et al., 2009).

The concept of addiction is generally discussed under two headings. When we examine behavioral addiction and substance addiction etiologically, it is understood that both addictions are similar (Karaman \& Kurtoğlu, 2009). For this reason, if the studies examining the effect of ACT on various types of addiction are reviewed, addiction-focused ACT studies are effective in both categories of addiction, behavioral and substance addiction. Twohig and Crosby (2010) found that there was a significant decrease in participants' levels of internet addiction after 
an ACT-focused group study. Similarly, Berenjabadi, Pourhosein, and Argene (2021) investigated the effect of ACT on high school students' internet addiction and interpersonal difficulties, and found that internet addiction and interpersonal difficulties were reduced at the end of the study. Another study results examining the effects of ACT on smartphone addiction level, self-control and anxiety levels of university students, showed that ACT was effective in reducing the level of anxiety and increasing the level of self-control, and indirectly in the treatment of smartphone addiction (Yu \& Son, 2016). Furthermore, Ercengiz (2019) examined the effect of the ACT-based psychoeducation program on social media addiction of individuals and determined that there was significant decrease in social media addiction that continued in the follow-up test. All these finding considered, ACT is and evidence based method effectively dealing with various types of addictions.

There is one study with the ACT approach, which pioneered the development of humor as a useful coping mechanism. Baisley and Grunberg (2019) tried to make the participants evaluate the humor they use as offensive, participatory, self-improving or self-defeating beyond mere intent, with the method they used in their research. It has also sought to provide a practical approach to understanding how and when humor can be adaptive using the techniques of the ACT. According to the findings of the study, participants' self-reported satisfaction levels increased and their sense of humor improved, but no change was observed in their motivation and self-efficacy levels. The preliminary data supported the validity and applicability of the developed application as a working humor education model.

\section{Limitations}

Findings from this study should be interpreted considering the limitations. While collecting data in our research, it was paid attention not to collect data only through social media in order to reduce the possibility of reaching those who use social media frequently. For this reason, the research link was delivered by using various communication platforms such as mail groups, instant messaging, and social media. There was no support or advertising from any organization. All scores obtained in the study showed a normal distribution. The fit indices of the tested model were on acceptable levels.

On the other hand, all the data were focused on the population of just one country. The generalizability of findings were limited due to the convenience sampling and the bias towards female participants. In this study, one hypothesised model was tested and it fitted the data. Alternative models that could produce the same result may also be examined with the same variables. Another limitation is that the study was designed as cross-sectional which is not sufficient to establish a causal relationship. Hence, the interpretation of the present findings should be made with caution. In spite of these limitations, this study is the first to explore the role of coronavirus anxiety, problematic social media use and coping humor on psychological flexibility during COVID-19 pandemic. 


\section{Future Directions}

Future research should investigate the causal links among these variables over time through a longitudinal or an experimental design. Moreover, while examining the relationship between COVID-19 anxiety and psychological flexibility in future studies, it is recommended to examine the effects of mediating variables such as intolerance to uncertainty, mindfulness, and social support. Besides, experimental designs will be useful to verify that enhancing the outcomes investigated can improve psychological flexibility. Also in this study, social media addiction, one of the sub-branches of technology addiction, was studied. Different branches of technology addiction can be included in the study and a more comprehensive content can be studied. Finally, the data was gathered in the later late period of the outbreak in Turkey. There might be differences between level of coronavirus anxiety at initial stage and latter (Lee, 2020).

\section{Conclusion}

During COVID-19 pandemic, psychological flexibility is affected by social media use, humor and coronavirus anxiety. The pandemic has adverse effects on mental health in approximately a quarter of the general population and psychological flexibility is one of the factors moderating these adverse effects on mental health (Pakenham et al., 2020). Besides, conducting training sessions and seminars which include various practices that will enable the increase of psychological flexibility can positively affect the mental health of the population. The effectiveness of these studies can be determined by experimental studies. Moreover, considering the findings, regulating the use of social media and supporting humor as a coping mechanism will have a positive influence on psychological flexibility of individuals that promotes mental health of population.

Data availability The datasets generated and/or analyzedbduring the current study are available from the corresponding author on reasonable request.

\section{Declarations}

Ethical Statement The study was approved by the Research Ethics Committee of Istanbul 29 Mayis University (Approval code: 2021/01-03) and conducted in accordance with the Helsinki Declaration of 1975, as revised in 2000. Informed consent was obtained from all patients for being included in the study.

Conflict of Interest The authors declare that they have no conflict of interest. 


\section{References}

Abel, M. H. (2020). Humor, stress, and coping strategies. Humor-International Journal of Humor Research, 15(4), 365-381. https://doi.org/10.1515/humr.15.4.365.

Agrawal, K., \& Singh, G. (2018). Social media and psychological distress among youth: A systematic review. Journal of Indian Social Science Association, 14, 43-52.

Akkuzu, H., Yumuşak, F. N., Karaman, G., Ladikli, N., Türkkan, Z., \& Bahadır, E. (2020). Koronavirüs Kaygı Ölçeği'nin Türkçe güvenirlik ve geçerlik çalışması. Kıbrıs Türk Psikiyatri ve Psikoloji Dergisi, 2(2), 63-67. https://doi.org/10.35365/ctjpp.20.2.09

Alabi, O. F. (2012). A survey of Facebook addiction level among selected Nigerian University undergraduates. New Media and Mass Communication, 10, 70-80.

Al-Kandari, Y.Y., \& Al-Sejari, M.M. (2021). Social isolation, social support and their relationship with smartphone addiction. Information, Communication \& Society 1-19. https://doi.org/10.1080/ 1369118X.2020.1749698

Amici, P. (2020). Humor in the age of COVID-19 lockdown: An explorative qualitative study. Psychiatria Danubina, 32(1), 15-20.

Andreassen, C. S., Billieux, J., Griffiths, M. D., Kuss, D. J., Demetrovics, Z., Mazzoni, E., \& Pallesen, S. (2016). The relationship between addictive use of social media and video games and symptoms of psychiatric disorders: A large-scale cross-sectional study. Psychology of Addictive Behaviors, 30(2), 252-262. https://doi.org/10.1037/adb0000160.

Arslan, G., \& Allen, K. A. (2021). Exploring the association between coronavirus stress, meaning in life, psychological flexibility, and subjective well-being. Psychology, Health \& Medicine, 1-12https:// doi.org/10.1080/13548506.2021.1876892

Baisley, M. C., \& Grunberg, N. E. (2019). Bringing humor theory into practice: An interdisciplinary approach to online humor training. New Ideas in Psychology, 55, 24-34. https://doi.org/10.1016/j. newideapsych.2019.04.006

Balc1, Ş., \& Tiryaki, S. (2014, June). Facebook Addiction among High School Students in Turkey. IISES Vienna 10th Internaional Academic Conference, Vienna, Austria.

Barry, R. R. (1994). Recognizing unconscious humor in psychoanalysis. In H. S. Strean (Ed.), The use of humor in psychotherapy (pp. 65-74). Jason Aronson.

Bendau, A., Petzold, M. B., Pyrkosch, L., Maricic, L. M., Betzler, F., Rogoll, J., Julia Große, J., Ströhle, A., \& Plag, J. (2020). Associations between COVID-19 related media consumption and symptoms of anxiety, depression and COVID-19 related fear in the general population in Germany. European archives of psychiatry and clinical neuroscience, 1-9https://doi.org/10.1007/s00406-020-01171-6

Bendau, A., Kunas, S. L., Wyka, S., Petzold, M. B., Plag, J., Asselmann, E., \& Ströhle, A. (2021). Longitudinal changes of anxiety and depressive symptoms during the COVID-19 pandemic in Germany: The role of pre-existing anxiety, depressive, and other mental disorders. Journal of anxiety disorders, 102377https://doi.org/10.1016/j.janxdis.2021.102377

Berenjabadi, M. F., Pourhosein, M., \& Argene, M. G. (2021). The Effectiveness of Acceptance and Commitment Therapy (ACT) on Interpersonal Difficulties and Internet Addiction among High School Students. Journal of Applied Psychological Research, 12(2), 283-301. https://doi.org/10.22059/ japr.2021.310151.643639

Blachino, A., Przepio'rka, A., \& Pantic, I. (2015). Internet Use, Facebook Intrusion, and Depression: Results of a Cross-Sectional Study. European Pyschiatry, 30, 681-684. https://doi.org/10.1016/j. eurpsy.2015.04.002

Bonaccorsi, G., Pierri, F., Cinelli, M., Flori, A., Galeazzi, A., Porcelli, F., ... \& Pammolli, F. (2020). Economic and social consequences of human mobility restrictions under COVID-19. Proceedings of the National Academy of Sciences, 117(27), 15530-15535https://doi.org/10.1073/pnas.2007658117

Bonnano, G. A. (2004). Loss, trauma and human resilience: Conceptual and empirical connections and separateness. American Psychologist, 59(1), 20-28.

Brunault, P., Champagne, A. L., Huguet, G., Suzanne, I., Senon, J. L., Body, G., ... \& Camus, V. (2015). Major depressive disorder, personality disorders, and coping strategies are independent risk factors for lower quality of life in non-metastatic breast cancer patients. Psycho-Oncology, 25, 513520https://doi.org/10.1002/pon.3947

Büyüköztürk, Ş., Çakmak, E.K., Akgün, Ö.E., Karadeniz, Ş., \& Demirel F. (2010). Bilimsel araştırma yöntemleri (5th ed.). Pegem Akademi. 
Cauberghe, V., Van Wesenbeeck, I., De Jans, S., Hudders, L., \& Ponnet, K. (2020). How adolescents use social media to cope with feelings of loneliness and anxiety during COVID-19 lockdown. Cyberpsychology, Behavior, and Social Networking, 1-8https://doi.org/10.1089/cyber.2020.0478

Celso, B., Ebener, D., \& Burkhead, E. (2003). Humor coping, health status, and life satisfaction among older adults residing in assisted living facilities. Aging \& Mental Health, 7(6), 438-445. https://doi. org/10.1080/13607860310001594691

Chan, T. H. (2014). Facebook and its effects on users' empathic social skills and life satisfaction: A double-edged sword effect. Cyberpsychology, Behavior, and Social Networking, 17(5), 276-280. https://doi.org/10.1089/cyber.2013.0466

Chin, F., \& Hayes, S. C. (2017). Acceptance and commitment therapy and the cognitive behavioral tradition: Assumptions, model, methods, and outcomes. In S. G. Hofmann \& G. J. G. Asmundson (Eds.), The science of cognitive behavioral therapy (pp. 155-173). Elsevier Academic Press.

Chou, W. P., Lee, K. H., Ko, C. H., Liu, T. L., Hsiao, R. C., Lin, H. F., \& Yen, C. F. (2017). Relationship between psychological inflexibility and experiential avoidance and internet addiction: Mediating effects of mental health problems. Psychiatry Research, 257, 40-44. https://doi.org/10.1016/j. psychres.2017.07.021

Ciarrochi, J., Bilich, L., \& Godsell, C. (2010). Psychological flexibility as a mechanism of change in acceptance and commitment therapy. In R. A. Baer (Ed.), Assessing mindfulness and acceptance processes in clients: Illuminating the Theory and Practice Of Change (pp. 51-75). New Harbinger Publications.

Collier, J. E. (2020). Applied structural equation modeling using AMOS: Basic to advanced techniques. Routledge.

Da Silva, M. L., Rocha, R. S. B., Buheji, M., Jahrami, H., \& Cunha, K. D. C. (2021). A systematic review of the prevalence of anxiety symptoms during coronavirus epidemics. Journal of Health Psychology, 26(1), 115-125. https://doi.org/10.1177/1359105320951620

Dawson, D. L., \& Golijani-Moghaddam, N. (2020). COVID-19: Psychological flexibility, coping, mental health, and wellbeing in the UK during the pandemic. Journal of Contextual Behavioral Science, 17, 126-134. https://doi.org/10.1016/j.jcbs.2020.07.010

De Cock, R., Vangeel, J., Klein, A., Minotte, P., Rosas, O., \& Meerkerk, G. (2014). Compulsive use of social networking sites in Belgium: Prevalence, profile, and the role of attitude toward work and school. Cyberpsychology, Behavior and Social Networking, 17(3), 166-171. https://doi.org/10. 1089/cyber.2013.0029

Demirci, İ. (2019). Bergen Sosyal Medya Bağımlılı̆̆ı Ölçeğinin Türkçeye uyarlanması, depresyon ve anksiyete belirtileriyle ilişkisinin değerlendirilmesi. Anatolian Journal of Psychiatry/anadolu Psikiyatri Dergisi, 20, 15-22. https://doi.org/10.5455/apd.41585

Donnelly, E., \& Kuss, D. J. (2016). Depression among users of social networking sites (SNSs): The role of SNS addiction and increased usage. Journal of Addiction and Preventive Medicine, 1(2), 107. https://doi.org/10.19104/japm.2016.107

Echeburua, E., \& de Corral, P. (2010). Addiction to New Technologies and to online social networking in young people: A new challenge. Adicciones, 22, 91-95.

Eifert, G. H., Forsyth, J. P., Arch, J., Espejo, E., Keller, M., \& Langer, D. (2009). Acceptance and commitment therapy for anxiety disorders: Three case studies exemplifying a unified treatment protocol. Cognitive and Behavioral Practice, 16(4), 368-385. https://doi.org/10.1016/j.cbpra.2009.06. 001

Eraslan-Capan, B. (2015). Interpersonal sensitivity and problematic Facebook use in Turkish university students. The Anthropologist, 21, 395-403. https://doi.org/10.1080/09720073.2015.11891829

Ercengiz, M. (2019). The Effectiveness of ACT based Psycho-Education Program on Social Media Disorder. International Online Journal of Educational Sciences, 11(1), 23-31. https://doi.org/10. 15345/iojes.2019.01.002

Ford, T. E., Ford, B. L., Boxer, C. F., \& Armstrong, J. (2012). Effect of humor on state anxiety and math performance. Humor, 25(1), 59-74. https://doi.org/10.1515/humor-2012-0004

Francis, A. W., Dawson, D. L., \& ve Golijani-Moghaddam, N. (2016). The development and validation of the Comprehensive assessment of Acceptance and Commitment Therapy processes (CompACT). Journal of Contextual Behavioral Science, 5, 134-145. https://doi.org/10.1016/j.jcbs.2016.05.003.

Frankl, V. E. (1966). Logotherapy and existential analysis-a review. American Journal of Psychotherapy, 20(2), 252-260. 
Fritz, H. L., Russek, L. N., \& Dillon, M. M. (2017). Humor use moderates the relation of stressful life events with psychological distress. Personality and Social Psychology Bulletin, 43(6), 845-859. https://doi.org/10.1177/0146167217699583.

Gao, J., Zheng, P., Jia, Y., Chen, H., Mao, Y., Chen, S., Wang, Y., Fu, H., \& Dai, J. (2020). Mental health problems and social media exposure during COVID-19 outbreak. PLoS ONE, 15(4), e0231924. https://doi.org/10.1371/journal.pone.0231924

George, D., \& Mallery, M. (2009). SPSS for windows step by step: A simple guide and reference 17.0 update (15. ed.). Routledge.

Gravetter, J. F., \& Forzano, L. B. (2012). Research methods for the behavioral sciences (4th ed.). Wadsworth.

Griffiths, M. D. A. (2005). A “components" model of addiction within a biopsychosocial framework. Journal of Substance Use, 10(4), 191-197. https://doi.org/10.1080/14659890500114359

Hajure, M., Tariku, M., Mohammedhussein, M., \& Dule, A. (2020). Depression, anxiety and associated factors among chronic medical patients amid COVID-19 pandemic in Mettu Karl Referral Hospital, Mettu, Ethiopia, 2020. Neuropsychiatric Disease and Treatment, 16https://doi.org/10.2147/ NDT.S281995

Han, E., Tan, M. M. J., Turk, E., Sridhar, D., Leung, G. M., Shibuya, K., ... \& Legido-Quigley, H. (2020). Lessons learnt from easing COVID-19 restrictions: an analysis of countries and regions in Asia Pacific and Europe. The Lancet, 396(10261), 1773-1734https://doi.org/10.1016/S0140-6736(20) 32007-9

Hashemi, S. G. S., Hosseinnezhad, S., Dini, S., Griffiths, M. D., Lin, C. Y., \& Pakpour, A. H. (2020). The mediating effect of the cyberchondria and anxiety sensitivity in the association between problematic internet use, metacognition beliefs, and fear of COVID-19 among Iranian online population. Heliyon, 6(10), e05135. https://doi.org/10.1016/j.heliyon.2020.e05135

Hayes, S. C., Barnes-Holmes, D., \& Roche, B. (2001). Relational frame theory: A post-Skinnerian account of human language and cognition. Kluver Academic Publishers.

Hayes, S. C., Bissett, R. T., Korn, Z., Zettle, R. D., Rosenfarb, I. S., Cooper, L. D., \& Grundt, A. M. (1999). The impact of acceptance versus control rationales on pain tolerance. Psychol Rec, 49(1), $33-47$.

Hayes, S. C., Luoma, J. B., Bond, F. W., Masuda, A., \& Lillis, J. (2006). Acceptance and commitment therapy: Model, processes and outcomes. Behaviour Research and Therapy, 44(1), 1-25. https:// doi.org/10.1016/j.brat.2005.06.006

Hayes, S. C., \& Smith, S. (2006). Get Out Your Mind \& Into Your Life. New Harbinger Publications Inc.

Hayes, S. C., Strosahl, K. D., \& Wilson, K. G. (2009). Acceptance and commitment therapy. American Psychological Association Press.

Hayes, S. C., \& Levin, M. E. (2012). Mindfulness \& acceptance for addictive behaviors. New Harbinger Publications.

Hayes, S. C., Villatte, M., Levin, M., \& Hildebrandt, M. (2011). Open, aware, and active: Contextual approaches as an emerging trend in the behavioral and cognitive therapies. Annual Review of Clinical Psychology, 7, 141-168. https://doi.org/10.1146/annurev-clinpsy-032210-104449.

Hoare, E., Milton, K., Foster, C., \& Allender, S. (2017). Depression, psychological distress and Internet use among community-based Australian adolescents: A cross-sectional study. BMC Public Health, 17, 365. https://doi.org/10.1186/s12889-017-4272-1

Hoffmann, D., Rask, C. U., \& Frostholm, L. (2019). Acceptance and Commitment Therapy for Health Anxiety. In E. Hedman-Lagerlöf (Ed.), The Clinician's Guide to Treating Health Anxiety (pp. 123142). Elsevier Academic Press.

Hu, L. T., \& Bentler, P. M. (1999). Cutoff criteria for fit indexes in covariance structure analysis: Conventional criteria versus new alternatives. Structural Equation Modeling, 6(1), 1-55. https://doi.org/ $10.1080 / 10705519909540118$

Junco, R. (2012). The relationship between frequency of Facebook use, participation in Facebook activities, and student engagement. Computers \& Education, 58, 162-171. https://doi.org/10.1016/j. compedu.2011.08.004

Karakuş, S., \& Akbay, S. E. (2020). Psikolojik Esneklik Ölçeği: Uyarlama, Geçerlik ve Güvenirlik Çalışması. Mersin Üniversitesi Ĕ̆itim Fakültesi Dergisi, 16(1), 32-43. https://doi.org/10.17860/ mersinefd. 665406

Karaman, K. M., \& Kurtoğlu, M. (2009). Öğretmen adaylarının internet bağımlılı̆̆ı hakkındaki görüşleri, Akademik Bilişim'09-XI. Akademik Bilişim Konferansı Bildirileri, 1(1), 641-650. 
Karpinski, A. C., Kirschner, P. A., Ozer, I., Mellott, J. A., \& Ochwo, P. (2013). An exploration of social networking site use, multitasking, and academic performance among United States and European university students. Computers in Human Behavior, 29, 1182-1192. https://doi.org/10.1016/j.chb. 2012.10.011

Keles, B., McCrae, N., \& Grealish, A. (2019). A systematic review: The influence of social media on depression, anxiety and psychological distress in adolescents. International Journal of Adolescence and Youth, 25(1), 79-93. https://doi.org/10.1080/02673843.2019.1590851.

Khattak, F. A., Ahmad, S., \& Mohammad, H. (2017). Facebook addiction and depression: A comparative study of gender differences. PUTAJ-Humanities and Social Sciences., 25(1-2), 55-62.

Király, O., Potenza, M. N., Stein, D. J., King, D. L., Hodgins, D. C., Saunders, J., ...\& Demetrovics, Z. (2020). Preventing problematic internet use during the COVID-19 pandemic: consensus guidance. Comprehensive Psychiatry, 100, 1-4https://doi.org/10.1016/j.comppsych.2020.152180

Kirschner, P. A., \& Karpinski, A. C. (2010). Facebook ${ }^{\circledR}$ and academic performance. Computers in Human Behavior, 26, 1237-1245. https://doi.org/10.1016/j.chb.2010.03.024

Kline, R. B. (2015). Principles and practice of structural equation modeling. Guilford publications.

Kuiper, N. A., Martin, R. A., \& Olinger, L. J. (1993). Coping humour, stress, and cognitive appraisals. Canadian Journal of Behavioural Science/Revue canadienne des sciences du comportement, 25(1), 81-96. https://doi.org/10.1037/h0078791

Kuiper, N. A., McKenzie, S. D., \& Belanger, K. A. (1995). Cognitive appraisals and individual differences in sense of humor: Motivational and affective implications. Personality and Individual differences, 19(3), 359-372.

Landi, G., Pakenham, K. I., Boccolini, G., Grandi, S., \& Tossani, E. (2020). Health anxiety and mental health outcome during COVID-19 lockdown in Italy: The mediating and moderating roles of psychological flexibility. Frontiers in Psychology, 11, 2195. https://doi.org/10.3389/fpsyg.2020.02195

Lee, S. A. (2020). Coronavirus Anxiety Scale: A brief mental health screener for COVID-19 related anxiety. Death Studies, 44(7), 393-401. https://doi.org/10.1080/07481187.2020.1748481

Li, Q., Miao, Y., Zeng, X., Tarimo, C. S., Wu, C., \& Wu, J. (2020). Prevalence and factors for anxiety during the coronavirus disease 2019 (COVID-19) epidemic among the teachers in China. Journal of Affective Disorders, 277, 153-158. https://doi.org/10.1016/j.jad.2020.08.017

Liu, S., Yang, L., Zhang, C., Xiang, Y., Liu, Z., Hu, S., \& Zhang, B. (2020). Online mental health services in China during the COVID-19 outbreak. The Lancet Psychiatry, 7(4), e17-e18. https://doi. org/10.1016/S2215-0366(20)30077-8

Lin, C. Y. (2020). Social reaction toward the 2019 novel coronavirus (COVID-19). Social Health and Behavior, 3(1), 1-2. https://doi.org/10.4103/SHB.SHB_11_20

Maiolino, N., \& Kuiper, N. (2016). Examining the impact of a brief humor exercise on psychological well-being. Translational Issues in Psychological Science, 2(1), 4-13. https://doi.org/10.1037/ tps0000065

Marino, C., Gini, G., Vieno, A., \& Spada, M. M. (2018). The associations between problematic Facebook use, psychological distress and well-being among adolescents and young adults: A systematic review and meta-analysis. Journal of Affective Disorders, 226, 274-281. https://doi.org/10.1016/j. jad.2017.10.007

Martin, R. A., \& Lefcourt, H. M. (1983). Sense of humor as a moderator of the relation between stressors and moods. Journal of Personality and Social Psychology, 45(6), 1313-1324.

Martin, R. A., Puhlik-Doris, P., Larsen, G., Gary, J., \& Weir, K. (2003). Individual differences in uses of humor and their relation to psychological well-being: Development of the Humor Styles Questionnaire. Journal of Research in Personality, 37, 48-75. https://doi.org/10.1016/S0092-6566(02) 00534-2

Masuda, A., \& Tully, E. C. (2012). The role of mindfulness and psychological flexibility in somatization, depression, anxiety, and general psychological distress in a nonclinical college sample. Journal of Evidence-Based Complementary \& Alternative Medicine, 17(1), 66-71. https://doi.org/10.1177/ 2156587211423400

McAlonan, G. M., Lee, A. M., Cheung, V., et al. (2007). Immediate and sustained psychological impact of an emerging infectious disease outbreak on health care workers. The Canadian Journal of Psychiatry, 52, 241-247. https://doi.org/10.1177/070674370705200406

McCracken, L. M., Badinlou, F., Buhrman, M., \& Brocki, K. C. (2021). The role of psychological flexibility in the context of COVID-19: Associations with depression, anxiety, and insomnia. Journal of Contextual Behavioral Science, 19, 28-35. https://doi.org/10.1016/j.jcbs.2020.11.003 
Menéndez-Aller, Á., Postigo, Á., Montes-Álvarez, P., González-Primo, F. J., \& García-Cueto, E. (2020). Humor as a protective factor against anxiety and depression. International Journal of Clinical and Health Psychology, 20(1), 38-45. https://doi.org/10.1016/j.ijchp.2019.12.002

Nezlek, J. B., \& Derks, P. (2001). Use of humor as a coping mechanism, psychological adjustment, and social interaction. Humor, 14(4), 395-414. https://doi.org/10.1515/humr.2001.011

Özbay, Y., Palancı, M., Kandemir, M., \& Çakır, O. (2012). Üniversite öğrencilerinin öznel iyi oluşlarının duygusal düzenleme, mizah, sosyal öz-yeterlik ve başaçıkma davranışları ile yordanması. Türk Eğitim Bilimleri Dergisi, 10(2), 325-345.

Özdamar, K. (2002). Paket programlar ile istatistiksel veri analizi (4. Bask1). Kaan Kitabevi.

Özdin, S., \& Bayrak-Özdin, Ş. (2020). Levels and predictors of anxiety, depression and health anxiety during COVID-19 pandemic in Turkish society: The importance of gender. International Journal of Social Psychiatry, 66(5), 504-511. https://doi.org/10.1177/0020764020927051.

Özgür, H. (2013). Öğretmen adaylarının sosyal ağ bağımlılığı, etkileşim kaygısı ve yalnızlık düzeyi arasındaki ilişkinin incelenmesi. International Journal of Human Sciences, 10(2), 667-690.

Pakenham, K. I., Landi, G., Boccolini, G., Furlani, A., Grandi, S., \& Tossani, E. (2020). The moderating roles of psychological flexibility and inflexibility on the mental health impacts of COVID19 pandemic and lockdown in Italy. Journal of Contextual Behavioral Science, 17, 109-118. https://doi.org/10.1016/j.jcbs.2020.07.003

Pelling, E. L., \& White, K. M. (2009). The theory of planned behavior applied to young people's use of social networking web sites. CyberPsychology \& Behavior, 12(6), 755-759. https://doi.org/ 10.1089/cpb.2009.0109

Pilz, R. (2018). Relations between Psychological Flexibility, Humor Styles and Pain and the Mediating Role of Well-Being [Master's thesis, Utrecht University]. Utrecht University Repository. https://dspace.library.uu.nl/handle/1874/395563

Pouralizadeh, M., Bostani, Z., Maroufizadeh, S., Ghanbari, A., Khoshbakht, M., Alavi, S. A., \& Ashrafi, S. (2020). Anxiety and depression and the related factors in nurses of Guilan University of Medical Sciences hospitals during COVID-19: A web-based cross-sectional study. International Journal of Africa Nursing Sciences, 13, 100233. https://doi.org/10.1016/j.ijans.2020. 100233

Preacher, K. J., \& Hayes, A. F. (2008). Asymptotic and resampling strategies for assessing and comparing indirect effects in multiple mediator models. Behavior Research Methods, 40(3), 879891. https://doi.org/10.3758/BRM.40.3.879

Rachlin, H. (2000). The Science of Self-Control. Howard University Press.

Rasskazova, E. I., Leontiev, D. A., \& Lebedeva, A. A. (2020). Pandemic as a challenge to subjective well-being: anxiety and coping. Counseling Psychology and Psychotherapy, 28(2), 90-108. https://doi.org/10.17759/CPP.2020280205

Rieger, A., \& McGrail, J. P. (2013). Coping humor and family functioning in parents of children with disabilities. Rehabilitation Psychology, 58(1), 89-97. https://doi.org/10.1037/a0031556

Ruch, W. (1998). The sense of humour: Explorations of a personality characteristic (1st ed.). Mouton de Gruyter.

Sagioglou, C., \& Greitemeyer, T. (2014). Facebook's emotional consequences: Why Facebook causes a decrease in mood and why people still use it. Computers in Human Behavior, 35, 359-363. https://doi.org/10.1016/j.chb.2014.03.003

Satıcı, S. A., \& Deniz, M. E. (2017). Mizahla başa çıkma ve iyilik hali: Psikolojik sağlamlık ve iyimserliğin aracılık rolünün incelenmesi. Ilköğretim Online, 16(3), 1343-1356. https://doi.org/ 10.17051/ilkonline.2017.330262

Savcı, M., \& Aysan, F. (2017). Teknolojik bağımlılıklar ve sosyal bağlılık: İnternet bağımlılığı, sosyal medya bağımlılı̆̆ı, dijital oyun bağımlılığı ve akıllı telefon bağımlılığının sosyal bağlılı̆̆1 yordayıc etkisi. Düşünen Adam the Journal of Psychiatry and Neurological Sciences, 30(3), 202-216. https://doi.org/10.5350/DAJPN2017300304

Scherr, S., \& Brunet, A. (2017). Differential influences of depression and personality traits on the use of Facebook. Social Media+ Society, 3(1), 1-14. https://doi.org/10.1177/2056305117698495

Scott, W., \& McCracken, L. M. (2015). Psychological flexibility, acceptance and commitment therapy, and chronic pain. Current Opinion in Psychology, 2, 91-96. https://doi.org/10.1016/j.copsyc. 2014.12.013

Smith, R. E., Ascough, J. C., Ettinger, R. F., \& Nelson, D. A. (1971). Humor, anxiety, and task performance. Journal of Personality and Social Psychology, 19(2), 243-246. https://doi.org/10.1037/ h0031305 
Smout, M. F., Longo, M., Harrison, S., Minniti, R., Wickes, W., \& White, J. M. (2010). Psychosocial treatment for methamphetamine use disorders: A preliminary randomized controlled trial of cognitive behavior therapy and acceptance and commitment therapy. Substance Abuse, 31, 98-107. https://doi.org/10.1080/08897071003641578

Soysal, M.N. (2016). Facebook bă̆ımlılı̆̆ı ve psikolojik dayanıklılık. [Unpublished master's thesis, Gelişim Üniversitesi]. http://acikerisim.gelisim.edu.tr/xmlui/bitstream/handle/11363/178/ 458746.pdf? sequence $=1 \&$ is Allowed $=y$

Stankovska, G., Angelkovska, S., \& Grncarovska, S. P. (2016). Social networks use, loneliness and academic performance among university students. Education provision to every one: Comparing perspectives from around the world. BCES Conference Books, 14 (1), 255-261.

Steers, M. N., Wickham, R. E., \& Acitelli, L. K. (2014). Seeing Everyone Else's HighlightReels: How Facebook Usage is Linked To Depressive Symptoms. Journal of Social and Clinical Pyschology, 33(8), 701-731. https://doi.org/10.1521/jscp.2014.33.8.701

Szabo, A. (2003). The acute effects of humor and exercise on mood and anxiety. Journal of Leisure Research, 35(2), 152-162. https://doi.org/10.1080/00222216.2003.11949988

Şimşek, Ö. F. (2007). Yapısal eşitlik modellemesine giriş (Temel ilkeler ve LISREL uygulamalart). Ekinoks.

Tavşancıl, E. (2010). Tutumların ölçülmesi ve SPSS ile veri analizi. Nobel Yayınları.

Taylor, S. (2019). The Psychology of Pandemics: Preparing for the Next Global Outbreak of Infectious Disease. Cambridge Scholars Publishing.

Taylor, S., Landry, C. A., Paluszek, M. M., \& Asmundson, G. J. G. (2020). Reactions to COVID19: Differential predictors of distress, avoidance, and disregard for social distancing. Journal of Affective Disorders, 277, 94-98. https://doi.org/10.1016/j.jad.2020.08.002

Teo, T., Tsai, L. T., \& Yang, C. C. (2013). Applying structural equation modeling (SEM) in educational research: An introduction. In M.S.Khine (Ed.), Application of structural equation modeling in educational research and practice (pp. 3-21). Brill Sense

Thorson, J., Powell, F., Sarmany-Schuller, I., \& Hampes, W. (1997). Psychological health and sense of humor. Journal of Clinical Psychology, 53(6), 605-619. https://doi.org/10.1002/(SICI)10974679(199710)53:6\%3c605::AID-JCLP9\%3e3.0.CO;2-I

Twohig, M. P. (2009). Acceptance and commitment therapy for treatment-resistant posttraumatic stress disorder: A case study. Cognitive and Behavioral Practice, 16(3), 243-252. https://doi. org/10.1016/j.cbpra.2008.10.002

Twohig, M. P. (2012). Acceptance and Commitment Therapy: Introduction. Cognitive and Behavioral Practice, 19, 499-507. https://doi.org/10.1016/j.cbpra.2012.04.003

Twohig, M. P., \& Crosby, J. M. (2010). Acceptance and Commitment Therapy as a treatment for problematic Internet pornography viewing. Behavior Therapy, 41(3), 285-295. https://doi.org/10. 1016/j.beth.2009.06.002

Valenzuela, S., Park, N., \& Kee, K. F. (2009). Is there social capital in a social network site?: Facebook use and college students' life satisfaction, trust, and participation. Journal of ComputerMediated Communication, 14, 875-901. https://doi.org/10.1111/j.1083-6101.2009.01474.x

Vela, L. E., Booth-Butterfield, M., Wanzer, M. B., \& Vallade, J. I. (2013). Relationships among humor, coping, relationship stress, and satisfaction in dating relationships: Replication and extension. Communication Research Reports, 30(1), 68-75. https://doi.org/10.1080/08824096. 2012.746224

Vilardaga, R., Estévez, A., Levin, M. E., \& Hayes, S. C. (2012). Deictic relational responding, empathy, and experiential avoidance as predictors of social anhedonia: Further contributions from relational frame theory. The Psychological Record, 62(3), 409-432. https://doi.org/10.1007/ BF03395811

Wang, C., Pan, R., Wan, X., Tan, Y., Xu, L., Ho, C. S., \& Ho, R. C. (2020). Immediate psychological responses and associated factors during the initial stage of the 2019 coronavirus disease (COVID-19) epidemic among the general population in China. International Journal of Environmental Research and Public Health, 17(5), 1729. https://doi.org/10.3390/ijerph17051729

We Are Social (2021, February 25). Digital in 2020, We are social. Retrieved from: https://weare social.com/digital- 2021

White, R. G., Gumley, A. I., McTaggart, J., Rattrie, L., McConville, D., Cleare, S., \& Mitchell, G. (2013). Depression and anxiety following psychosis: Associations with mindfulness and psychological flexibility. Behavioural and Cognitive Psychotherapy, 41(1), 34. https://doi.org/10.1017/S1352 465812000239 
Wielgus, B., Urban, W., Patriak, A., \& Cichocki, Ł. (2020). Examining the Associations between Psychological Flexibility, Mindfulness, Psychosomatic Functioning, and Anxiety during the COVID-19 Pandemic: A Path Analysis. International Journal of Environmental Research and Public Health, 17(23), 8764. https://doi.org/10.3390/ijerph17238764

Wilson, K. G., Hayes, S. C., \& Byrd, M. R. (2000). Exploring compatibilities between acceptance and commitment therapy and 12-step treatment for substance abuse. Journal of Rational-Emotive and Cognitive-Behavior Therapy, 18(4), 209-234. https://doi.org/10.1023/A:1007835106007

Wolniczak, I., Caceres-DelAguila, J. A., Palma-Ardiles, G., Arroyo, K. J., Solís-Visscher, R., ParedesYauri, S., \& Bernabe-Ortiz, A. (2013). Association between Facebook dependence and poor sleep quality: A study in a sample of undergraduate students in Peru. PLoS One, 8, e59087. https://doi. org/10.1371/journal.pone.0059087

Wu, A. M., Cheung, V. I., Ku, L., \& Hung, E. P. (2013). Psychological risk factors of addiction to social networking sites among Chinese smartphone users. Journal of Behavioral Addictions, 2, 160-166. https://doi.org/10.1556/JBA.2.2013.006

Yeni- Elbay, R., Kurtulmuş, A., Arpacioğlu, S., \& Karadere, E. (2020). Depression, anxiety, stress levels of physicians and associated factors in Covid-19 pandemics. Psychiatry Research, 290, 113130. https://doi.org/10.1016/j.psychres.2020.113130

Yerlikaya, E. E. (2009). Üniversite öğrencilerinin mizah tarzlart ile algllanan stres, kaygı ve depresyon düzeyleri arasındaki ilişkinin incelenmesi [Unpublished doctoral dissertation, Çukurova Üniversitesi]. http://libratez.cu.edu.tr/tezler/7665.pdf

Yu, H. G., \& Son, C. (2016). Effects of ACT on smartphone addiction level, self-control, and anxiety of college students with smartphone addiction. Journal of Digital Convergence, 14(2), 415-426. https://doi.org/10.14400/JDC.2016.14.2.415

Publisher's Note Springer Nature remains neutral with regard to jurisdictional claims in published maps and institutional affiliations. 